\title{
Occurrence of imposex and seasonal patterns of gametogenesis in the invading veined rapa whelk Rapana venosa from Chesapeake Bay, USA
}

\author{
Roger Mann, Juliana M. Harding*, Erica Westcott \\ Department of Fisheries Science, Virginia Institute of Marine Science, College of William and Mary, Gloucester Point, \\ Virginia 23062-1346, USA
}

\begin{abstract}
The prevalence and intensity of imposex and observations on the seasonal gametogenic cycle are reported for the Asian veined rapa whelk Rapana venosa (Valenciennes, 1846), an invader of the Chesapeake Bay on the North American Atlantic coast. Adult whelks from opportunistic collections by commercial fishermen demonstrated inactivity from mid-November through early March, copulation from February through mid-November, and egg-laying activity from late May through August. All imposex females examined did not have a functional vas deferens (below Stage 3 on the vas deferens scale of Gibbs et al. 1987; J Mar Biol Assoc UK 67:507-523) and were expected to function normally in reproduction. Although a preponderance of imposex females over 'normal' females by a ratio exceeding 2:1 was observed in 4 out of 5 regions examined in lower Chesapeake Bay, there was no significant difference in the numbers of functional females (imposex females and normal females) observed in any region. Shell lengths and wet tissue weights $(\mathrm{g})$ of both imposex females and males were approximately the same and sexual dimorphism was not apparent at the population level. However, true female rapa whelks had lower wet tissue weights than either imposex females or males. Individual rapa whelks did not appear to be food-limited in the Chesapeake Bay, and the described reproductive activity suggests continued invasion within Chesapeake Bay habitats.
\end{abstract}

KEY WORDS: Rapana venosa · Veined rapa whelk · Chesapeake Bay · Imposex · Biological invasion · Gametogenesis · Gastropod

Resale or republication not permitted without written consent of the publisher

\section{INTRODUCTION}

Over the course of recent history there has been an extended rearrangement of global shallow water marine and estuarine biota associated with human exploration, colonization and, subsequently, trade (Carlton 1996, 1999a). Major vectors for these organisms have changed from hull attached fouling organisms to ballast water associated planktonic species and pelagic early life history stages. The impacts of an invading species on novel (receptor) environments are ultimately bounded by the physical tolerances of the invader (Vermeij 1996). Interactions with native species including competition, predation, parasitism and disease further reduce these boundaries of influence and define the spatial and temporal boundaries within which the in- vaders are afforded the opportunity to reproduce and establish self-perpetuating populations. Marine and estuarine molluscs are well represented in the census of invading species that have become established in novel environments (Carlton 1999b). Although a variety of reproductive strategies are evident among these successful molluscan invaders, the traits of longevity associated with early maturation and high fecundity are notable assets in initial establishment and subsequent range extension in novel environments.

The veined rapa whelk Rapana venosa is native to the Sea of Japan, Yellow Sea, East China Sea and the Bohai Sea (Tsi et al. 1983), but has become established as an invading species in the Black Sea, Aegean Sea, eastern and central Mediterranean, and the Chesapeake Bay of the North American Atlantic coast (Hard- 
ing \& Mann 1999, 2005, Mann \& Harding 2000, Mann et al. 2004). In addition, there are reports suggesting nascent populations in the Rio del Plata (Pastorino et al. 2000) and the French coastline of the English Channel (P. Gouletqueller, IFREMER, pers. comm.). Rapa whelks are large predatory gastropods with broad environmental tolerances (J.M. Harding \& R. Mann 1999, Mann \& Harding 2000, 2003) and a reproductive strategy employing maturity at small size and young age (Chukchin 1984, J. M. Harding \& R. Mann unpubl. data), longevity estimated at approximately $15 \mathrm{yr}$ with no evidence of senescence (J. M. Harding \& R. Mann unpubl. data), high fecundity and multiple egg laying events per year (Ware 2002), and extended pelagic larval development to facilitate local dispersal (Mann \& Harding 2003). Indeed, the $50 \mathrm{yr}$ advance of the invasion of the species westward from the eastern Black Sea to the western Mediterranean suggests that, in the presence of suitable habitat and food supply and the absence of predators and equal competitors, reproductive output or propagule pressure (Williamson 1996) defines the rate of the invasion in that location. Under these conditions, the invasion front advances into spatially attractive and patchy situations, typically a mix of soft and hard substrates (Bombace et al. 1994), where rapa whelks occupy the habitat as apex predators and develop reproductive populations that, in a metapopulation sense (Hanski 1994, Dias 1996), become exporting sources of reproductive propagules.

Anthropogenic environmental hazards to which rapa whelks have not developed a suitable adaptive response present one challenge to the advancing invasion by compromising one or more elements of the reproductive cycle. Imposex, i.e. the imposition of male sexual characters including a penis and vas deferens onto females (e.g. Smith 1971, Gibbs et al. 1987, 1988, Stickle \& Zhang 2003) has been described in over 70 species of gastropods (Oehlmann et al. 1991). In this contribution, we document the incidence of imposex in the Chesapeake Bay rapa whelk population and discuss the impact of imposex on reproductive activity of this whelk in this novel environment.

\section{MATERIALS AND METHODS}

Source of whelks. Since 1998, the Virginia Institute of Marine Science (VIMS) has sponsored a bounty program for rapa whelks collected in the lower Chesapeake Bay. Rapa whelks $>70 \mathrm{~mm}$ shell length (SL) are collected as bycatch in the extant oyster Crassostrea virginica, hard clam Mercenaria mercenaria, blue crab Callinectes sapidus and local whelk Busycotypus canaliculatus and Busycon carica commercial fisheries in the Chesapeake Bay. Each fishery relies on distinct sampling gear, and the areas fished vary seasonally depending upon the target organism and management regulations. Although the bounty program is an opportunistic method for sample collection and is clearly dependent on fishery activity, the end product of the cooperation between VIMS and the commercial fishermen is an efficient sampling method for rapa whelks in the Chesapeake Bay that had produced over 6600 individual whelks as of August 2003. These rapa whelks had been collected regularly from 5 major regions in the lower Chesapeake Bay comprising the James River between the State Route 258 bridge and the MonitorMerrimac Bridge Tunnel (Region 1: Fig. 1); Hampton Bar, delineated by Monitor-Merrimac Bridge Tunnel upriver and the Hampton Roads Bridge Tunnel downriver (Region 2: Fig. 1), Ocean View, Little Creek and Lynnhaven Inlet or the area directly south and inshore of the Thimble Shoals shipping channel (hereafter Ocean View) (Region 3: Fig. 1); the Lafayette River (Region 4: Fig. 1); and the York River/Mobjack Bay system (Region 5: Fig. 1).

Morphological relationships, population sex ratios and gonadosomatic indices. Between September 1998 and June 2002, 863 rapa whelks collected through the bounty program (SL $>70 \mathrm{~mm}$ ) were sacrificed to provide descriptive information on rapa whelk morphology and population sex ratios in Chesapeake Bay habitats. Rapa whelks are reproductively active in the Black Sea at shell lengths of 35 to $78 \mathrm{~mm}$ (Chukhchin 1984) and shell lengths of 33 to $168 \mathrm{~mm}$ in Korea (Chung et al. 1993). Rapa whelks cultured in the Chesapeake Bay at VIMS held at ambient York River temperature and salinity conditions are reproductively active at shell lengths above 35 to $40 \mathrm{~mm}$ (J. M. Harding \& R. Mann unpubl. data). Thus all whelks used in this study (all $>70 \mathrm{~mm} \mathrm{SL}$ ), were capable of reproductive activity on the basis of size.

At the time of sacrifice, shell length, wet tissue weight, and penis length were among the data recorded. Each whelk was classified as female, imposex female or male using penis length and gonad color as diagnostic features: females had penis lengths of 0 (no penis) and gonads that were completely yellow in color; imposex females had penis lengths ranging from 1.9 to $25 \mathrm{~mm}$ and gonads that were either completely yellow or a mix of yellow and pale orange; males were characterized by penis lengths $>15 \mathrm{~mm}$ and gonads that were bright orange-red. The wet weight of the gonad and digestive gland (g) was recorded from individuals collected between September 1998 and August $2001(\mathrm{n}=440)$. A gonadosomatic index (GSI) was calculated for these 440 individuals with the equation:

$$
\text { GSI }=\frac{\text { gonad and digestive gland wet tissue wt }(\mathrm{g})}{\text { whelk wet tissue wt }(\mathrm{g})} \times 100
$$




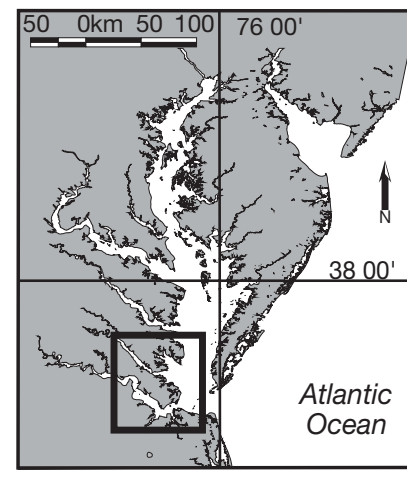

Fig. 1. Rapana venosa. Lower Chesapeake Bay, USA, showing area from which $>90 \%$ of Chesapeake Bay rapa whelks had been collected as of February 15, 2005 (dark grey shading; Harding \& Mann 2005). Within this area, regions from which rapa whelks were collected for this study are shaded black (1: James River; 2: Hampton Bar; 3: Ocean View, Little Creek, and Lynnhaven Inlet; 4: Lafayette River, and 5; York River; Mobjack Bay)

Histological examination of gonads. The gonads were dissected from a subset of Chesapeake Bay rapa whelks collected from March 1999 through May 2001 and were examined histologically to confirm complete gametogenesis by rapa whelks in a non-native habitat and quantitatively describe their reproductive state in relation to season. The number of whelks available for these analyses was limited by the frequency of whelk donations from commercial fishermen to the VIMS bounty program, in that rapa whelk collections are opportunistic and whelks of specific sexes were needed at monthly intervals. All samples were dehydrated in alcohol and embedded in paraffin using standard histological methods (Westcott 2001), sectioned at $10 \mu \mathrm{m}$ thickness, stained with Harris hematoxylin and eosin $\mathrm{Y}$, and examined under a compound microscope.

Gonadal synchrony. Gonads from 3 rapa whelk males and 3 imposex females collected in June 1999 were examined to determine if rapa whelk gonadal development is asynchronous (only 1 developmental stage present) or synchronous (multiple developmental stages within a gonad). A total of 3 sections from each gonad (anterior, middle and posterior) were collected and processed for these 6 whelks.

Gonad development. Overall gonad development was evaluated by microscopic examination of a single $5 \mathrm{~mm}$ wide section excised from the middle portion of each gonad. Rapa whelk gonadal sections ( $\mathrm{n}=15$ true females, 31 imposex females and 49 males) were examined to describe gonad development stage after Chung et al. (1993) and Chung \& Kim (1997). Males were categorized as either (1) developing, (2) mature, (3) spent or (4) recovering. The developing stage was characterized by a lack of spermatozoa: only sperm

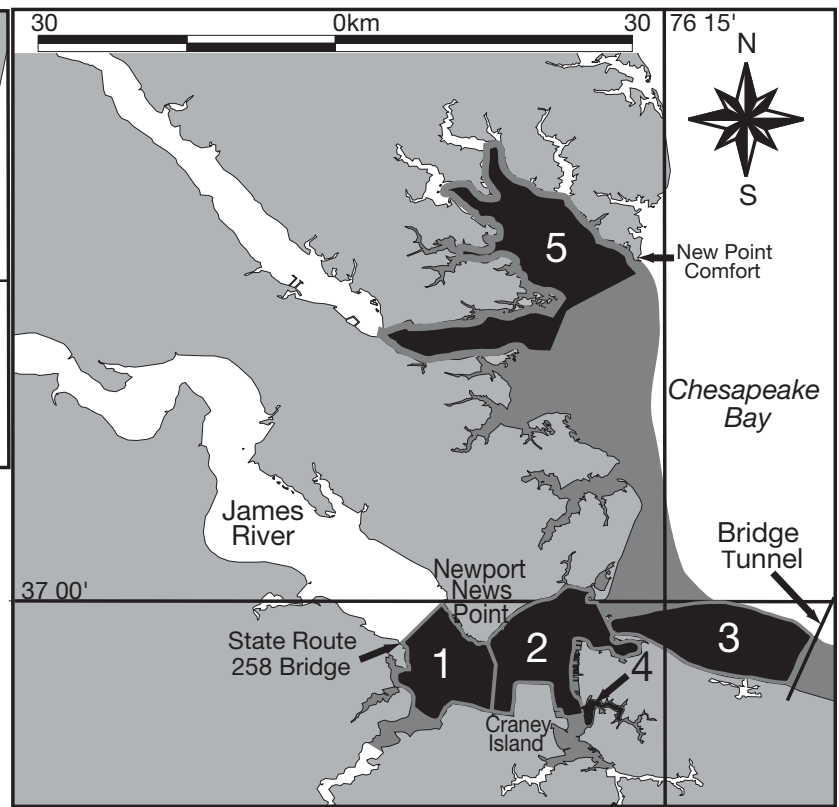

precursors (spermatogonia, spermatocytes, spermatids) were present. A gonad in the mature stage contained a large quantity of spermatozoa. A recovering stage male gonad contained few spermatozoa and spermatids intermingled with connective tissue in the lumen of the testicular lobes (Chung et al. 1993).

Normal and imposex females were categorized after Chung et al. (1993) as either (1) early growing, (2) late growing, (3) mature, (4) spent, or (5) recovering. Early growing gonads contained ooyctes 60 to $70 \mu \mathrm{m}$ in diameter with a round nucleus and a visible nucleolus. In the late growing stage, ooyctes ranged from 120 to $150 \mu \mathrm{m}$ in diameter and there were yolk granules in the cytoplasm of the oocyte. Ovaries in the mature stage contained ooyctes 190 to $240 \mu \mathrm{m}$ in diameter with visible yolk granules and a gelatinous outer membrane. During the recovery stage in female gonads, the ovarian lobules are greatly reduced in size and contain only newly formed oogonia (Chung et al. 1993). In this study, egg diameter was also measured in Stages 1 to 3 to assist in more accurately staging female gonads. We measured 10 eggs from each slide examined (11 true females, 20 imposex females) using an image-analysis system. Egg diameters of 60 to 70,120 to 150, and 190 to $240 \mu \mathrm{m}$ were diagnostic of the early developing, late developing, and mature stages, respectively.

Evaluation of Chesapeake Bay imposex rapa whelks with VDS index. We dissected 4 imposex rapa whelks to evaluate the progression of imposex as indicated by gross morphological features in the reproductive system of afflicted females. The development of imposex in Chesapeake Bay rapa whelks was characterized using the vas deferens sequence (VDS) index described by Gibbs et al. (1987): normal females with 


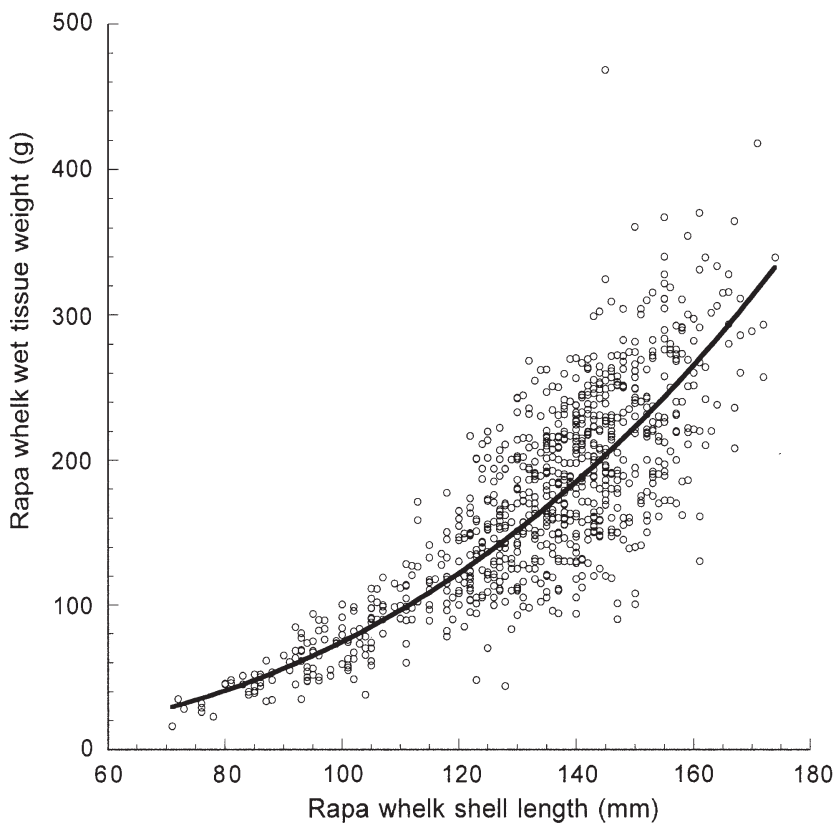

Fig. 2. Rapana venosa. Shell length in relation to wet tissue weight for 863 rapa whelks collected in Chesapeake Bay from 1999 to 2001. Equation for power regression is given in 'Results' and regression coefficients in Table 1

no signs of a penis or vas deferens are equivalent to Stage 0 ; commencement of vas deferens growth near the genital papilla constitutes Stage 1. In Stage 2 females, penis development is initiated and vas deferens growth near the genital papilla continues; Stage 3 females have a small penis and vas deferens growth is initiated at the base of the penis; during Stage 4, the vas deferens fuses and imposex female penis length is comparable to that of a male; Stage 5 females have vas deferens tissue overgrowing the genital papilla, and hyperplasia may also occur; a Stage 6 imposex female is considered to be 'grossly affected,' wherby the capsule gland lumen contains aborted egg capsules and the female is effectively sterile.

Data analyses. Significance levels for all statistical tests were established a priori at $\mathrm{p}=0.05$. When needed, Tukey's test was used for post-hoc, parametric, multiple comparisons and Dunn's test for post-hoc, non-parametric multiple comparisons. Unless otherwise noted, data satisfied assumptions of homogeneity of variance and normality without transformation.

Morphological relationships: Data from gross dissections of 862 adult specimens collected between January 1999 and May 2002 were used to describe the relationship between rapa whelk shell length and wet tissue weight as well as rapa whelk wet tissue weight and penis length.

Population sex ratios: The percentages of functional females (females and imposex females combined) were compared to the percentages of males across regions with a 2 -sample $t$-test.

Population sexual dimorphism: Wet tissue weight of females, imposex females and males was compared across sexes with a Kruskal-Wallis test since the data did not satisfy assumptions of homogeneity of variance and normality regardless of the transformation (logarithm, natural logarithm, square-root, reciprocal).

Gonadosomatic indices: GSI values, i.e. the percentage of the whelk's weight contributed by the gonad and digestive gland, were compared with an ANOVA using sex, quarter of the year or season, and collection site as factors. Individuals collected within the same quarters of the year were pooled across years.

\section{RESULTS}

\section{Morphological relationships}

The relationship between rapa whelk shell length and wet tissue weight (depicted in Fig. 2 was described using a power relationship (Table 1) given by the equation: wet tissue weight $(\mathrm{g})=0.001 \times$ shell length $(\mathrm{mm})^{2.43} ; \mathrm{R}^{2}=0.64, \mathrm{n}=863$.

Rapa whelk wet tissue weight has been used herein as the metric for size to accommodate potential changes in body weight with season. Unlike the whelk shell, which does not shrink after deposition (although

Table 1. Rapana venosa. Summary of regression coefficients and relationships used to describe Chesapeake Bay rapa whelk morphological relationships presented in Figs. $2 \& 3$

\begin{tabular}{|lccccc|}
\hline Relationship & Model & Coefficients & $\begin{array}{c}\text { SE } \\
\text { coefficients }\end{array}$ & $\begin{array}{c}\text { p-value } \\
\text { coefficients }\end{array}$ & $\begin{array}{c}\text { Regression } \\
\text { F-value }\end{array}$ \\
\hline Shell length:wet tissue wt & Power & $a=0.001$ & $a=2.47$ & $a=0.01$ & 1588.52 \\
& & $b=2.43$ & $b=32.43$ & $b=<0.01$ & $<0.01$ \\
Wet tissue wt:penis length & Power & $a=0.63$ & $a=0.28$ & $a=0.02$ & 48.79 \\
Imposex females & & $b=0.54$ & $b=0.08$ & $b=<0.01$ & 616.24 \\
Males & & $a=4.51$ & $a=0.42$ & $a=<0.01$ & $<0.01$ \\
& $b=0.41$ & $b=0.02$ & $b=<0.01$ & \\
\hline
\end{tabular}


it may be chipped), rapa whelk wet tissue weight depends upon food availability and the physiological condition of the whelk among other factors, and may vary as a function of these factors although the whelk's shell length will remain the same as the body shrinks or grows. As indicated in Fig. 2, a single shell length may correspond to a range of body weights.

Penis length was related to rapa whelk wet tissue weight for imposex females and males (true females, penis length $=0$ ) using power relationships (Table 1 , Fig. 3) described by the equations: imposex female penis length $(\mathrm{mm})=0.63 \times$ wet tissue weight $(\mathrm{g})^{0.54}$; $\mathrm{R}^{2}=0.19, \mathrm{n}=214 ;$ and male penis length $(\mathrm{mm})=4.51 \times$ wet tissue weight $(\mathrm{g})^{0.41} ; \mathrm{R}^{2}=0.54, \mathrm{n}=519$.

\section{Population sex ratios}

There was no significant difference observed between the percentages of functional females (females and imposex females combined) and males within each of the 5 regions of interest in Chesapeake Bay (Table 2; Student's $t$-test, $t=-2.07, \mathrm{df}=9, \mathrm{p}=0.07$ ).

\section{Population sexual dimorphism}

Female rapa whelks had significantly lower wet tissue weights than imposex females and males (Table 3 ). On average, female rapa whelks have lower wet tissue weights (average wet tissue weight $=152.45$, standard error of the mean, SEM $=8.34, \mathrm{n}=114$ ) than either imposex females $(175.09 \mathrm{~g}, \mathrm{SEM}=4.94, \mathrm{n}=215)$ or males (177.22 g, SEM = 2.79, $\mathrm{n}=522$ ). Given these results, wet tissue weights of female whelks were subsequently compared across season, pooled across years. Collection region was also evaluated as a factor for the 3 regions from which the most females had been collected (i.e. James River, Hampton Bar and Ocean View). Neither collection region nor season significantly affected female body weight (Table 3).

Imposex female and male body weights were compared across the 3 regions for which whelks were collected in each region (James River, Hampton Bar and Ocean View) and season using two 1-way ANOVA after transformation (logarithm). The data would not satisfy assumptions of either homogeneity of variance or normality when a 2way ANOVA was attempted, regardless of the transformation, and these data were too unbalanced to use a Friedman's rank analysis.

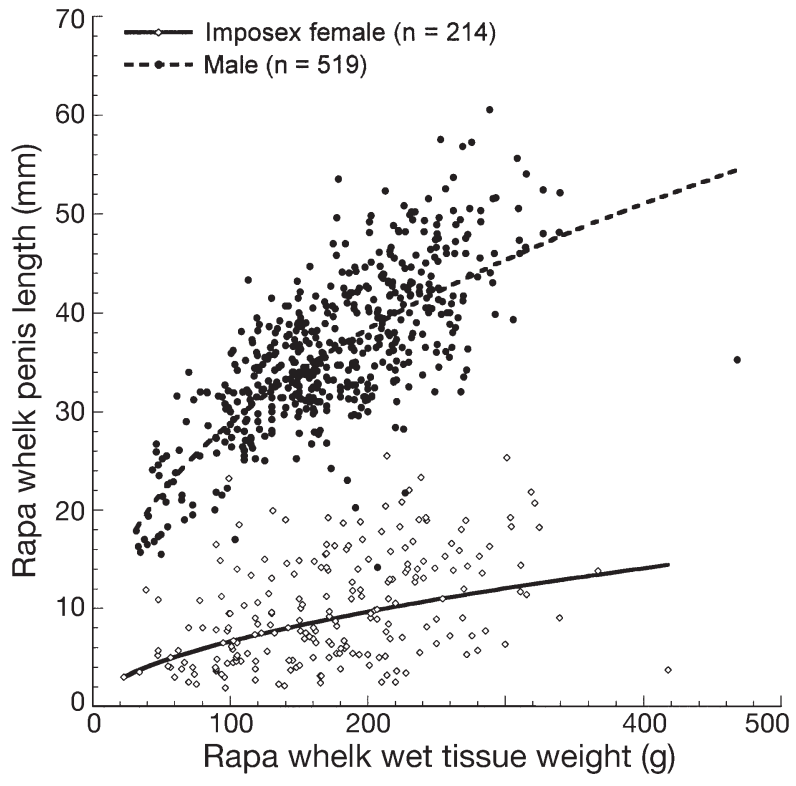

Fig. 3. Rapana venosa. Wet tissue weight in relation to penis length for imposex females and males collected in Chesapeake Bay from 1999 to 2001. Equations for sex-specific regressions are given in 'Results' and regression coefficients in Table 3

Collection region and season affected body weight of rapa whelk males and imposex females (ANOVAs, Table 3). Whelks collected from Ocean View (average body weight of 179.8 , standard error of the mean, $\left.\mathrm{SEM}_{1}=4.3, \mathrm{n}=217\right)$ and James River $(181.6 \mathrm{~g}, \mathrm{SEM}=$ $3.5, \mathrm{n}=318$ ) were heavier than whelks collected from Hampton Bar (145.3 g, SEM = 7.3, n = 42). Imposex female and male rapa whelks collected from July through December weighed less than whelks collected in other months (Table 3). Imposex female and male rapa whelks collected between January and March (average body weight of $218.0 \mathrm{~g}, \mathrm{SEM}=4.7, \mathrm{n}=194$ ) were heavier than whelks collected from April through June (166.9 $\mathrm{g}, \mathrm{SEM}=4.1, \mathrm{n}=239)$ as well as July through December $(146.2 \mathrm{~g}$, SEM $=4.6, \mathrm{n}=127)$.

Table 2. Rapana venosa. Summary of observed sex ratios and shell length (SL) ranges for rapa whelk populations sampled in lower Chesapeake Bay from January 1999 through May 2002. Only whelks from specified collection locations were used for these comparisons $(\mathrm{n}=820)$. Regions are delineated on Fig. 1 (1: James River; 2: Hampton Bar; 3: Ocean View; 4: Lafayette River; 5: York River and Mobjack Bay)

\begin{tabular}{|c|c|c|c|c|c|c|c|}
\hline \multirow[t]{2}{*}{ Region } & \multirow{2}{*}{$\begin{array}{c}\text { Females } \\
\text { (F) }\end{array}$} & \multirow{2}{*}{$\begin{array}{l}\text { No.of } \\
\text { Imposex } \\
\text { (I) }\end{array}$} & \multirow[b]{2}{*}{$\begin{array}{c}\text { Males } \\
\text { (M) }\end{array}$} & \multirow{2}{*}{$\begin{array}{c}\text { Functional } \\
\text { sex ratio } \\
(\mathrm{F}+\mathrm{I}): \mathrm{M}\end{array}$} & \multicolumn{3}{|c|}{ — SL range $(\mathrm{mm})$} \\
\hline & & & & & Female & Imposex & Male \\
\hline 1 & 17 & 113 & 206 & $120: 206$ & $94-167$ & $85-163$ & $84-166$ \\
\hline 2 & 6 & 16 & 26 & $22: 26$ & $140-159$ & $94-159$ & $105-157$ \\
\hline 3 & 86 & 66 & 209 & $154: 209$ & $71-167$ & $78-171$ & $76-174$ \\
\hline 4 & 1 & 6 & 5 & $7: 5$ & 105 & $105-130$ & $126-131$ \\
\hline 5 & 3 & 11 & 49 & $14: 49$ & $123-167$ & $95-157$ & $88-166$ \\
\hline
\end{tabular}


Table 3. Rapana venosa. Summary of statistical tests performed. Significance levels were established a priori at $\mathrm{p}=0.05$. Tukey's multiple comparison test was used for parametric multiple comparisons. Dunn's test was used for non-parametric multiple comparisons. GSI = gonadosomatic index

\begin{tabular}{|c|c|c|c|c|c|c|}
\hline Test & Factor & Response & df & $\mathrm{F} / \mathrm{H}$ value & $\mathrm{p}$-value & Multiple comparison test results \\
\hline Kruskal-Wallis & Sex & Wet tissue wt & 2 & 13.16 & $<0.01$ & Females < Imposex, Males \\
\hline ANOVA & Season & Female wet tissue wt & 3 & 0.07 & 0.97 & \\
\hline Kruskal-Wallis & Site & Female wet tissue wt & 2 & 3.25 & 0.20 & \\
\hline ANOVA & Site & Imposex + male wet tissue wt & 2 & 3.6 & 0.03 & $\begin{array}{l}\text { Hampton Bar < Ocean View, } \\
\text { James River }\end{array}$ \\
\hline ANOVA & Season & Imposex + male wet tissue $\mathrm{wt}$ & 3 & 29.1 & $<0.01$ & $\begin{array}{l}\text { Jan-Mar > Apr-Jun > Jul-Sep, } \\
\text { Oct-Dec }\end{array}$ \\
\hline \multirow{3}{*}{ ANOVA } & Sex & GSI & 2 & 10.57 & $<0.01$ & Females, Imposex > Male \\
\hline & Season & & 3 & 36.67 & $<0.01$ & $\begin{array}{l}\text { Jul-Sep }>\text { Oct-Dec }>\text { Apr-Jun }> \\
\text { Jan-Mar }\end{array}$ \\
\hline & Site & & 2 & 2.30 & 0.10 & \\
\hline
\end{tabular}

\section{Gonadosomatic indices (GSI)}

GSI values were significantly higher in rapa whelk females and imposex females than in males (ANOVA, Table 3, Fig. 4). GSI values observed from July through September were higher than those observed any other time of the year (ANOVA, Table 3, Fig. 4). This time period corresponds to the end of the egglaying season (usually mid-August in Chesapeake Bay) and a period of increased food consumption and somatic growth typically observed from late August through September in cultured individuals at VIMS (J. M. Harding \& R. Mann unpubl. data). The lowest GSI values were observed from January through March (ANOVA, Table 3, Fig. 4), a time frame corresponding to very low water temperatures and the end of the annual overwintering period during which activity and food consumption observed in laboratory holding tanks are typically at very low levels (if observed at all).

\section{Gonad synchrony}

Of the 3 male rapa whelk examined, 1 had a completely synchronous gonad, while the other 2 male whelk gonads were not entirely synchronous. In each of the asynchronous males, the slides prepared from the spire section of gonad lagged behind the middle and opercular sections in the stage of development; In one male, the opercular and middle sections were at late-copulation, while the spire section was midcopulation, while the other male had opercular and middle sections at mid-copulation stage with the spire section mature. All 3 gonad sections examined from 3 imposex females collected in June were synchronous and mature with egg diameters in the range 190 to $240 \mu \mathrm{m}$.

\section{Male gonad development}

Gonads from 49 male rapa whelks collected in March, April, May, June and October (1999-2001) from Chesapeake Bay were examined histologically to evaluate seasonal gonad development patterns. The developing stage was characterized by the presence of numerous spermatogonia, spermatocytes and spermatids, and the presence of spermatozoa in the seminal vesicle. Male rapa whelks were in the developing

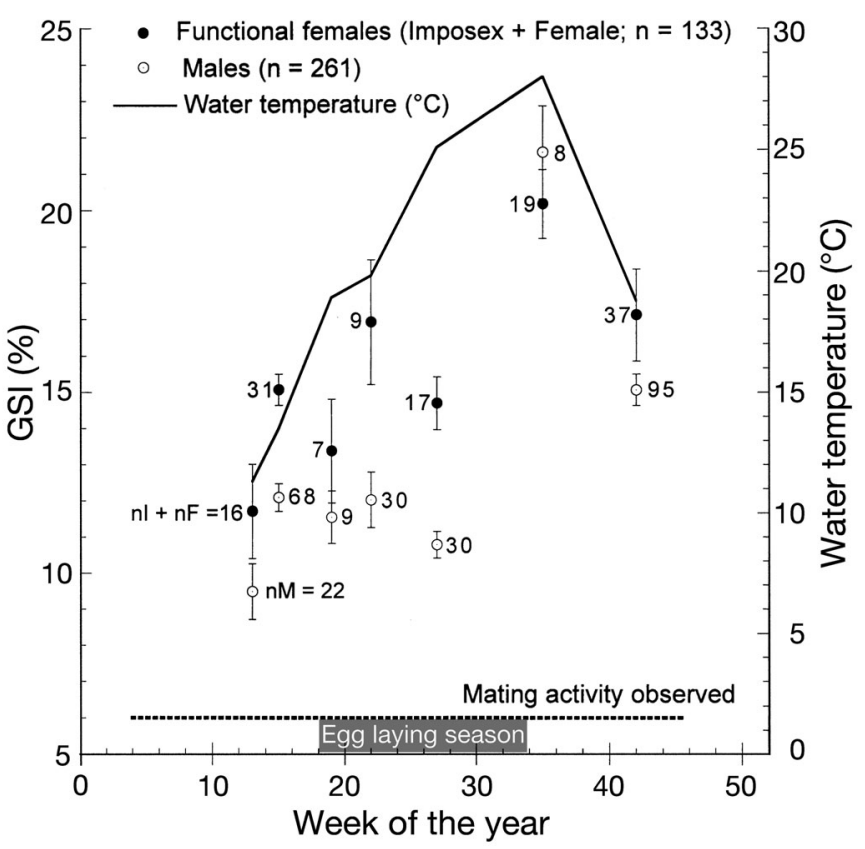

Fig. 4. Rapana venosa. Average $( \pm \mathrm{SE})$ monthly GSI (gonad wet wt + digestive gland wet wt [g]/tissue wet wt [g]) for Chesapeake Bay rapa whelks in relation to ambient water temperature. Numbers to left of a data point: number of functional females (imposex and normal) sampled; number to right of a data point: number of males sampled 
stage from March through May, when water temperatures were between 9 and $15^{\circ} \mathrm{C}$ (Fig. 5B,C). Mature stage male whelks with seminiferous tubule lumens filled with mature spermatozoa were present from May through October when water temperatures were between 15 and $28^{\circ} \mathrm{C}$ (Fig. 5B,C). Male whelks in the copulation stage were also observed from May through October. During this stage, the center of each lumen gradually becomes empty until only a few spermatozoa and sperm precursors remain. In October, at water temperatures of approximately $20^{\circ} \mathrm{C}, 25 \%$ of the male whelks examined were in the recovery stage (Fig. 5B,C) and degradation of the remaining spermatozoa was observed.

\section{Female gonad development}

Gonad development was identical in female $(\mathrm{n}=15)$ and imposex $(\mathrm{n}=31)$ rapa whelks. Female gonads in the early growing stage contained a number of oogonia budding from the germinal epithelium and many small oocytes. Within the lumen, a number of free yolk granules were present, and these stained a bright pink or magenta. Smaller oocytes contained only a few small yolk granules, while larger oocytes had taken up a larger proportion of yolk granules over time. Female rapa whelks from Chesapeake Bay were in the early growing stage during May at water temperatures of 15 to $20^{\circ} \mathrm{C}$ (Fig. 5A,B).

In the late growing stage, the majority of the yolk granules had been taken up from the lumen, although oogonia were still budding from the germinal epithelium. Female whelks in the late developing stage were found from March through May at water temperatures of $<15^{\circ} \mathrm{C}$ (Fig. 5A,B).

During the mature stage, large eggs completely fill the lumen and a few oogonia are present along the germinal epithelium. Mature eggs may appear polygonal in shape instead of being round or ovate, because they are so large and are competing for space. The nuclei of mature eggs were surrounded by very fine yolk granules and aligned near the center of the lumen. Female whelks in the mature stage were found from March through June at water temperatures from 9 to $20^{\circ} \mathrm{C}$ (Fig. 5A,B).

When the lumen is emptied of mature eggs during the copulation stage, the central lumen contains only a few scattered yolk granules. Oogonia and small oocytes remain attached to the germinal epithelium. Female whelks in the copulation stage were observed during October at water temperatures of $20^{\circ} \mathrm{C}$ (Fig. 5A,B). Recovery stage females, characterized by the presence of newly formed oogonia in the ovarian lobules, were not observed (Fig. 5).

\section{Evaluation of Chesapeake Bay imposex rapa whelks with VDS index}

All imposex rapa whelks collected from Chesapeake Bay that were examined were either Stage 2 or Stage 3 on the VDS scale (Gibbs et al. 1987). All of the whelks possessed a small penis (relative to that of true males) and none of them had a vas deferens that was fused.
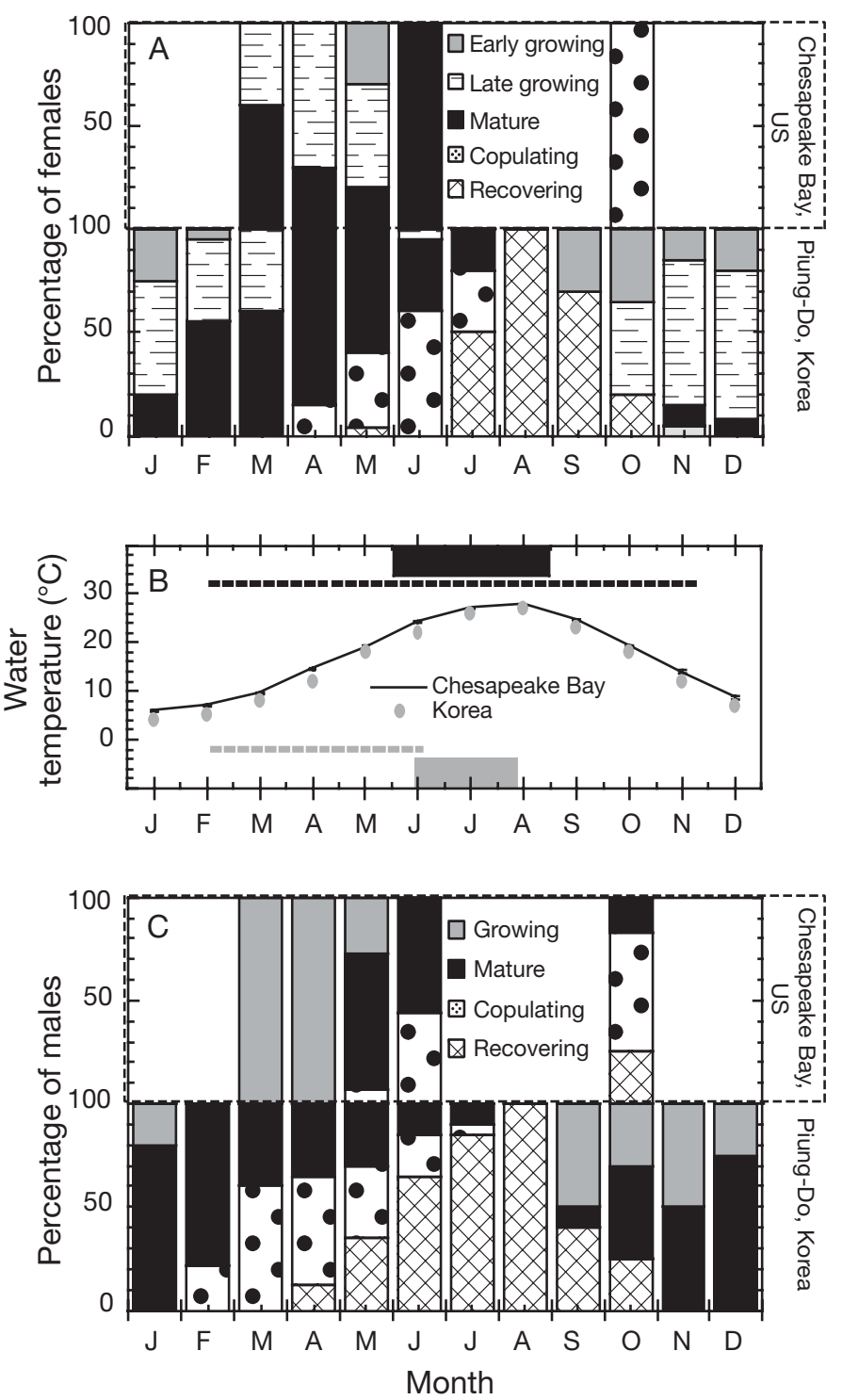

Fig. 5. Rapana venosa. Stages of gonadal development observed in (A) females and (C) males in relation to (B) water temperature in Chesapeake Bay (top) and Korean (bottom) waters. Korean rapa whelk data from Chung et al. (1993) and Chung \& Kim (1997); Korean water temperature data from Chung et al. (1993). In (B) solid blocks indicate observed periods of egg laying activity in Chesapeake Bay (black) and Korea (grey). Dashed lines delineate periods when mating has been observed in Chesapeake Bay (black) and Korea (grey) 


\section{DISCUSSION}

Despite the preponderence of imposex females over 'normal' females (penis length $=0$ ) by at least a 2:1 ratio in 4 out of 5 geographic regions examined, imposex does not appear to compromise reproductive ability of Chesapeake Bay rapa whelk females. All imposex females examined were Stage 2 or Stage 3 on the VDS scale of Gibbs et al. (1987), did not have a functional vas deferens, and were expected to function normally in reproduction. The observed ratios of functional females (imposex females and 'normal' females) to males were similar across geographic regions described from lower Chesapeake Bay. There are no reported observations of imposex in rapa whelks from native populations in Korea (Chung et al. 1993) or other introduced populations (e.g. Black Sea: Chuchkin 1984, Zolotarev 1996).

In the Chesapeake Bay population, shell lengths and wet tissue weights of both imposex females and males are approximately the same and sexual dimorphism is not apparent at the population level. Since the development of imposex in gastropods is related to cumulative exposure to tributyltin (TBT) and related chemical compounds (e.g. Smith 1971, Gibbs et al. 1987, 1988, Bryan \& Gibbs 1991, Mensink et al. 1996, Oberdorster \& McClellan-Green 2002, Stickle \& Zhang 2003), it is possible that female whelks are younger than imposex female whelks and have thus been exposed to environmental sources of TBT for less time. TBT is a documented environmental pollutant in the Chesapeake Bay (Unger et al. 1986, Bryan et al. 1989, Huggett et al. 1996), and concentrations between 1 and $100 \mathrm{ng} \mathrm{l}^{-1}$ (Unger et al. 1986, Huggett et al. 1996, www.vims.edu/ env/projects/tbt_deq/index.html) have been observed in the regions where rapa whelks have been collected (Harding \& Mann 1999 and this paper). Additional research is needed both on the length-at-age relationships for rapa whelks and development of imposex in this whelk in relation to environmental sources of TBT.

While overall wet tissue weights were different between imposex and normal female rapa whelks from Chesapeake Bay, the gonadosomatic index (GSI) values for imposex and normal females were not statistically different from each other, but both had GSI values that were statistically higher than those observed in male whelks. GSI values for both sexes generally followed the seasonal patterns in water temperature (Fig. 4), and the highest GSI values were observed during the months with the warmest water temperatures. Populations of Chesapeake Bay rapa whelks held at ambient temperature conditions in flow-through systems at Gloucester Point display strong seasonal patterns in feeding activity and reproductive behavior (egg-laying and mating) as well as locomotion in relation to ambient water temperatures (J. M. Harding \& R. Mann unpubl. data).
GSI values for Korean populations of rapa whelk males (Chung et al. 1993, Chung \& Kim 1997) and females (Chung et al. 1993) rely on measurements of gonad thickness in relation to the diameter of the posterior appendage (gonad + digestive gland) rather than on the tissue weight-based index calculated herein. In Korea, there is an inverse relationship between the GSI values and water temperature for both males and females. The highest GSI values have been observed during the months of December and January (males) and January, February, and March (females), corresponding to the lowest water temperatures. The observed differences between Chesapeake Bay and Korean GSI values may in part be methodological; however, the observed differences suggest differing seasonal responses to the local environment in native and invading populations. On the basis of external observations, the egg-laying season for Chesapeake Bay rapa whelks begins earlier and lasts longer than that observed for Korean whelks (Fig. 5B). Chesapeake Bay whelks held in flow-through conditions in the laboratory have been observed copulating or mating from February-March through mid-November, that is, at water temperatures above approximately $8^{\circ} \mathrm{C}$. Copulation in Korean populations has been described only from February through June (Chung et al. 1993), but it is unclear whether this characterization is based on observations of adults in the field or laboratory (as in Chesapeake Bay) or on histological data only.

Histological examination of Chesapeake Bay rapa whelk populations suggests normal gametogenesis and fully functional members of both sexes. While both males and females in Chesapeake Bay undergo stages of gonad development similar to those described for Korean populations (Chung et al. 1993, Chung \& Kim 1997), the progression of gonad development observed for both sexes in relation to water temperature or month in the present study differs from the pattern described for Korean individuals (Chung et al. 1993, present Fig. 5). Gametogenic activity in Korean whelks increases in the spring with increasing water temperature, is at a maximum in May and June just prior to the egg-laying season, and then remains in the recovery phase as water temperatures decline in the fall and into the winter months (Fig. 5). In contrast, Chesapeake Bay reproductive activity of rapa whelks appears to extend over a longer temporal window that includes the fall months (Fig. 5). Chesapeake Bay males and females do not appear to spend as much time in the recovering stage as their Korean counterparts. Thus far, growth and reproductive activity by Chesapeake Bay populations of rapa whelks do not appear to be food limited, indeed the sizes of specimens observed in the Chesapeake Bay rival the sizes of the largest Korean individuals observed (Green 2001). 
Potential differences between the Korean (Chung et al. 1993, Chung \& Kim 1997) and Chesapeake Bay (Westcott 2001, present paper) patterns include sample collection methods, sampling intervals and sizes of whelks examined. Chung et al. (1993) and Chung and Kim (1997) relied on samples collected monthly with a dredge at the same site. Chesapeake Bay samples were collected opportunistically through the VIMS bounty program and included representatives from potentially many locations within a region collected with different gear types. Examination of the size ranges of whelks collected and the resulting functional sex ratios (see above and Table 2) indicates that all sizes and sexes of rapa whelks are well-represented in Chesapeake Bay collections. The opportunistic nature of sample collection in the Chesapeake Bay resulted in sampling intervals that corresponded to fishing activity rather than to months, and in an irregular number of samples (individuals). The resultant collections are the product of fishing activity by commercial fishermen over a minimum period of 4 mo and a maximum period of 1 yr. Chung et al. (1993) did not present the numbers or sizes of individuals sampled on a monthly basis, so comparisons at these levels are not possible.

Although examination of multiple histological sections for individual Chesapeake Bay whelks for June collections showed no asynchrony in development within the gonad of individual females, asynchrony was observed in 2 of 3 males examined. The presence and prevalence of asynchrony in either sex at other times of the year is unknown. For all months other than June, only 1 gonad section from the middle of each gonad was examined and used to characterize gonad development for Chesapeake Bay specimens. Chung et al. (1993) did not indicate the location or number of sections used for histological determination of gonad development and did not address asynchrony in Korean populations.

Rapa whelks are the focus of a commercial fishing industry in their native waters. Overfishing combined with habitat changes (Chung et al. 1993, Chung \& Kim 1997) has led to declines in rapa whelk abundance in Korean waters. The impact of these changes on mating frequency and seasonal behavior are unknown. In Chesapeake Bay, the geographic distribution of rapa whelks is concentrated in regions south of New Point Comfort, west of the Chesapeake Bay Bridge Tunnel, and east of the State Route 258 bridge over the James River (Fig. 1, see also Harding \& Mann 2005). As on February 15, 2005, > 90\% of the 10232 rapa whelks collected in the Chesapeake Bay have been collected within these boundaries (Harding \& Mann 2005). Although absolute population estimates are not available, this aggregated distribution suggests that individuals may encounter each other frequently and may be able to mate year-round or at least during those times of the year when rapa whelk activity is moderate to high. During the overwintering period in Chesapeake Bay, from mid-November through early March, no mating has been observed in flow-through holding tanks (J. M. Harding \& R. Mann unpubl. data) nor reported from field collections by commercial fishermen.

Chesapeake Bay rapa whelks occupy habitats historically contaminated with TBT (Unger et al. 1986, Huggett et al. 1996) at concentrations ranging from 1 to $100 \mathrm{ng} \mathrm{l}^{-1}$ (Unger et al. 1986, www.vims.edu/env/ projects/tbt_deq/index.html). Predatory infaunal gastropods like rapa whelks are exposed to TBT in the sediments into which they burrow, the food that they eat (bioaccumulation), and the water in which they live. Stickle et al. (1990) described development of imposex in Nucella lima during laboratory experiments as a result of exposure to either seawater or mussel prey items containing TBT. While imposex development has been observed in gastropods at environmental concentrations of TBT as low as $2 \mathrm{ng} \mathrm{l}^{-1}$ (Nucella lapillus, Gibbs et al. 1988, Bryan et al. 1989), the threshold for imposex development in rapa whelks is unknown. Both TBT and dibutyltin (DBT) have been observed in Chesapeake Bay rapa whelks (Jestel 2003). Body burdens of rapa whelks collected from different locations within Chesapeake Bay are under investigation (E. Jestel, M. Unger, J. M. Harding, R. Mann unpubl. data), as is the relationship between environmental concentrations of TBT, rapa whelk body burdens and imposex development (M. Unger, J. M. Harding \& R. Mann unpubl. data).

Observations of imposex in Chesapeake Bay rapa whelks thus far are restricted to modest external morphological variations that do not appear to compromise the female's ability to reproduce. At the population level, functional sex ratios remain approximately equal, propagule pressure, the rate at which breeding individuals are released by adults (Williamson 1996), is not reduced, and the presence of imposex does not compromise the continuing invasion of Chesapeake Bay environment by rapa whelks.

Acknowledgements. Support for this project was provided by Virginia Sea Grant (R/MG-98-3), Commercial Saltwater Fishing Development Fund (CF-98-19), NOAA Aquatic Nuisance Species Program, and the Department of Fisheries Science, Virginia Institute of Marine Science. Special thanks are extended to local watermen, and to seafood processors who donated adult rapa whelks to our research collection. We thank Melissa Southworth, Steven Goodbred, Catherine Goodbred, Rhonda Howlett, Stephanie Haywood, Alex Jestel, David Kerstetter, and Catherine Ware for assistance with field collections and sample processing. Nita Walker, Rita Crockett, Jeff Shields, and Dave Zwerner provided assistance with histology. This is Contribution Number 2727 from the Virginia Institute of Marine Science. 


\section{LITERATURE CITED}

Bombace G, Fabi G, Fiorentini L, Speranza S (1994) Analysis of the efficacy of artificial reefs located in five different areas of the Adriatic Sea. Bull Mar Sci 55:559-580

Bryan G, Gibbs P (1991) Impact of low concentrations of tributyltin (TBT) on marine organisms: a review. In: Newman MC, McIntosh W (eds) Metal ecotoxicity, concepts and applications. Lewis Publishers, Boston, MA, p 323-361

Bryan G, Gibbs P, Burt G (1988) A comparison of the effectiveness of tri-n-butyl tin chloride and five other organotin compounds in promoting the development of imposex in the dog whelk Nucella lapillus. J Mar Biol Assoc UK 68: 733-744

Bryan G, Gibbs P, Huggett R, Curtis L, Bailey D, Dauer D (1989) Effects of tributyltin pollution on the mud snail, Ilyanassa obsolete, from the York River and Sarah Creek, Chesapeake Bay. Mar Pollut Bull 20:458-462

Carlton JT (1996) Pattern, process and prediction in marine invasion ecology. Biol Conserv 78:97-106

Carlton JT (1999a) The scale and ecological consequences of biological invasions in the world's oceans. In: Sandlund OD, Schei PJ, Viken A (eds) Invasive species and biodiversity management. Kluwer Academic Press Publishers, Dorchrecht, p 195-212

Carlton JT (1999b) Molluscan invasions in marine and estuarine communities. Malacologia 41:439-454

Chukchin V (1984) Ecology of the gastropod molluscs of the Black Sea. Naukova Dumka, Academy of Sciences of the USSR, Kiev (in Russian)

Chung E, Kim S (1997) Cytological studies on testicular maturation and cyclic changes in the epithelial cells of the seminal vesicle of the male purple shell, Rapana venosa (Gastropoda: Muricidae). Malacol Rev 30:25-38

Chung E, Kim S, Kim Y (1993) Reproductive ecology of the purple shell, Rapana venosa (Gastropoda: Muricidae), with special reference to the reproductive cycle, depositions of egg capsules and hatchings of larvae. Korean J Malacol 9:1-15

Dias PC (1996) Sources and sinks in population biology. Trends Ecol Evol 11:326-330

Gibbs P, Bryan G, Pascoe P, Burt G (1987) The use of the dog whelk Nucella lapillus as an indicator of tributyltin (TBT) contamination. J Mar Biol Assoc UK 67:507-523

Gibbs P, Pascoe P, Burt G (1988) Sex change in the female dog whelk Nucella lapillus, induced by tributyltin from antifouling paints. J Mar Biol Assoc UK 68:715-731

Green R (2001) Morphological variation of three populations of the veined rapa whelk, Rapana venosa, an invasive predatory gastropod species. MSc thesis, College of William and Mary, Williamsburg, VA

Hanski I (1994) Patch-occupancy dynamics in fragmented landscapes. Trends Ecol Evol 9:131-135

Harding JM, Mann R (1999) Observations on the biology of the veined rapa whelk, Rapana venosa (Valenciennes, 1846) in the Chesapeake Bay. J Shellfish Res 18:9-17

Harding JM, Mann R (2005) Veined rapa whelk Rapana venosa range extensions in the Virginia waters of Chesapeake Bay, USA. J Shellfish Res 24:381-385

Huggett R, Evans D, MacIntyre W, Unger M, Seligman P, Hall L Jr (1996) Tributyltin concentration in waters of the Chesapeake Bay. In: Champ MA, Seligman PF (eds) Trib-

Editorial responsibility: Kenneth L. Heck (Contributing Editor), Dauphin Island, Alabama, USA utyltin: environmental fate and effects. Chapman \& Hall Publishers, New York, p 485-502

Jestel E (2003) Imposex as an indicator of butyltin exposure in the veined rapa whelk (Rapana venosa): a Chesapeake Bay invader. MSc thesis, College of William and Mary, Williamsburg, VA

Mann R, Harding JM (2000) Invasion of the North American Atlantic coast by a large predatory Asian mollusc. Biol Invasions 2:7-22

Mann R, Harding JM (2003) Salinity tolerances of larval Rapana venosa: implications for dispersal and establishment of an invading predatory gastropod on the North American Atlantic coast. Biol Bull (Woods Hole) 204: 96-103

Mann R, Occhipinti A, Harding JM (2004) Alien species alert: Rapana venosa (veined whelk). Int Counc Explor Sea Coop Res Rep 264:1-14

Mensink B, Everaarts J, Kralt H, ten Hallers-Tjabbes C, Boon J (1996) Tributyltin exposure in early life stages induces the development of male sexual characteristics in the common whelk, Buccinum undatum. Mar Environ Res 42:151-154

Oberdorster E, McClellan-Green P (2002) Mechanism of imposex induction in the mud snail Ilyanassa obsoleta: TBT as a neurotoxin and aromatase inhibitor. Mar Environ Res 54:715-718

Oehlmann, JJ Stroben, Fiorini P (1991) The morphological expression of imposex in Nucella lapillus (Linneaus) (Gastropoda: Muricidae). J Molluscan Stud 57:375-390

Pastorino G, Penchaszadeh PE, Schejter L, Bremec C (2000) Rapana venosa (Valenciennes, 1846) (Mollusca: Muricidae: a new gastropod in South Atlantic waters. J Shellfish Res 19:897-899

Smith B (1971) Sexuality in the American mud snail, Nassarius obsoletus Say. Proc Malacol Soc Lond 39:377-78

Stickle W, Zhang Z (2003) Long term trends in imposex in six populations of Stramonita haemastoma. Bull Mar Sci 72: 685-694

Stickle W, Sharp-Dahl J, Rice S, Short J (1990) Imposex induction in Nucella lima (Gmelin) via mode of exposure to tributyltin. J Exp Mar Biol Ecol 143:165-180

Tsi CY, Ma XT, Lou ZK, Zhang FS (1983) Illustrations of the fauna of China (Mollusca), Vol 2. Science Press, Beijing

Unger M, MacIntyre W, Greaves JR, Huggett (1986) GC determination of butyltins in natural waters by flame photometric detection of hexyl derivatives with mass spectrometric confirmation. Chemosphere 15:461-470

Vermeij G (1996) An agenda for invasion biology. Biol Conserv 78:3-9

Ware C (2002) Temporal and spatial variation in reproductive output of the veined rapa whelk (Rapana venosa) in the Chesapeake Bay. MSc thesis, College of William and Mary, Williamsburg, VA

Westcott E (2001) Seasonal reproductive activity of the invading gastropod Rapana venosa in the Chesapeake Bay. MSc thesis, College of William and Mary, Williamsburg, VA

Williamson M (1996) Biological invasions. Chapmann \& Hall, New York

Zolotarev V (1996) The Black Sea ecosystem changes related to the introduction of new mollusc species. PSZN I: Mar Ecol 17:227-236

Submitted: July 7, 2004; Accepted: August 26, 2005

Proofs received from author(s): March 6, 2006 